\title{
The Optimal Portfolio of JII Shares Listed on the Indonesian Stock Exchange: The Single Index Model Approach
}

\author{
Tri Agus Setyo and Augustina Kurniasih
}

\begin{abstract}
This study aims to determine and analyze the optimal portfolio forming stocks using the Single Index Model, determine the optimal portfolio risk and return expectations, then compare the optimal portfolio risk and return expectations with market return expectations, then analyze the optimal portfolio performance using the Treynor model. The research was conducted on the Jakarta Islamic Index stocks. Population of 48 issuers, which meet the sample criteria of 14 issuers. Using monthly data for the period December 2014November 2019, it was found that 2 stocks entered the optimal portfolio, is (with a proportion of funds) ICBP $(91.46 \%)$ and TLKM $(8.54 \%)$. The value of $E(R p) 0.0128$ is greater than the value of $E(R M) 0.0003$ and the value of the risk free rate is 0.0048. The value of $\sigma p 0.0438$ is greater than the value of $\sigma 2 \mathrm{M}$ 0.0364. The portfolio performance value with the Treynor index of 0.0091 is greater when compared to the market of 0.0045 .
\end{abstract}

Index Terms - JII Index, Optimal Portfolio, Single Index Model, Treynor.

\section{INTRODUCTION}

The behavior of investors in investing stocks very diverse, there are investors who are long-term investors, some are speculators, and there are also those who run both simultaneously. Decisions in implementing an investment strategy are based on the level of expected returns or returns received, as well as the risks faced. The return and risk factors must be calculated carefully in order to get investment returns as expected.

Indonesia Stock Exchange (IDX) plays an important role in raising funds from investors who then channel it for company development. Table 1 below shows the performance of the Indonesian capital market which includes the development of the number of publicly traded companies, daily trading average, and the composite stock price index.

The Indonesian capital market in the last five years has experienced an increase in listed companies. This means that the company believes that the capital market is the best place to get funds or capital apart from bank credit. The increase in the number of listed companies on the stock exchange was also accompanied by an increase in the average daily trading. On the other hand, the JCI as a

Published on December 5, 2020.

Tri Agus Setyo

(e-mail: triagussetyo3@gmail.com)

Augustina Kurniasih

(e-mail: augustina.kurniasih@mercubuana.co.id). measure of capital market progress fluctuated.

\begin{tabular}{ccccc}
\multicolumn{4}{c}{ TABLE 1: INDONESIA CAPITAL MARKET PERFORMANCE } \\
\hline \multirow{2}{*}{ Year } & $\begin{array}{c}\text { Total of } \\
\text { Listed } \\
\text { Companies }\end{array}$ & $\begin{array}{c}\text { Daily Trading Average } \\
\text { Volume } \\
\text { (Million } \\
\text { Shares) }\end{array}$ & $\begin{array}{c}\text { Value } \\
\text { (IDR }\end{array}$ & JCI \\
Billion) & Development \\
\hline 2015 & 521 & 5.980 & $5.766,23$ & $4.593,01$ \\
2016 & 537 & 7.912 & $7.504,99$ & $5.296,71$ \\
2017 & 566 & 12.241 & $7.618,05$ & $6.355,65$ \\
2018 & 619 & 12.431 & $8.530,64$ & $6.194,65$ \\
2019 & 668 & 15.014 & $9.122,66$ & $6.329,31$ \\
\hline
\end{tabular}

As a country with the largest Muslim population in the world, the Islamic economic system is here to accommodate the needs of the Indonesian people, especially Muslim people who want to invest funds in stocks that comply with sharia principles. The criteria for issuing sharia shares have been regulated in a decision by the Capital Market Supervisory Agency for Financial Institutions (BAPEPAMLK) in the decree of the chairman of Bapepam-LK No. KEP-208/BL/2012. There are currently two Islamic stock indexes on the Indonesia Stock Exchange, namely the Jakarta Islamic Index (JII) and the Indonesian Sharia Stock Index (ISSI)

There are 30 issuers in JII, reviews of Islamic stocks that are JII constituents are conducted twice a year, following the schedule of reviews of the Sharia Securities List (DES) and the Financial Services Authority (OJK). On the other hand, there are 398 issuers that are included in the ISSI index based on the latest announcement of changes in share composition in the calculation of ISSI No. Peng00213/BEI.POP/05-2019. The difference in the number of issuers of JII and ISSI makes JII easier to consider when Indonesians are going to invest in Islamic stocks.

Oktaviani \& Wijayanto [2] research shows that JII produces a greater portfolio expected return than that produced by the LQ45 index. This is in accordance with the statement reported by medcom.id [3], that JII is more resilient and able to withstand slowing economic conditions compared to conventional indexes. This is influenced by the capital structure of issuers that are included in the JII index related to interest income and debt ratio limits which affect the company's resilience during macroeconomic downturns and changes in BI rate regulations.

People who invest in stocks generally expect returns. But on the other hand, there are risks that must be faced. One of the most important assumptions is that in general all investors do not like risk (risk averse), so the concept of diversification is very helpful for investors who do not like 
risk. Through diversification, which is spreading investment into several assets, it is hoped that the risk will be smaller [4]. Diversification is a concept used in the formation of an optimal portfolio. The optimal portfolio can assist investors in making investment decisions so that they can generate maximum returns with minimal risk. The optimal portfolio can be formed with a variety of models, one of which is the Single Index Model.

The Single Index Model was introduced by William F. Sharpe in 1963 to simplify the input parameters in the calculation of the Markowitz model [2]. In addition, the Single Index Model considers aspects of the market and aspects of the uniqueness of the company. Septyanto \& Kertopati [5] believe that continuous addition to a portfolio, at a certain point will further reduce the benefits of diversification and will actually increase the level of risk. This study also resulted in the value of the expected return of the Single Index Model higher than the Markowitz Model.

For the construction portfolio, it is necessary to evaluate performance. The model used to measure portfolio performance in general is the Sharpe, Treynor, and Jensen model [6]. The Sharpe model is a calculation by comparing the portfolio risk premium (the difference between the average portfolio profit rate and the risk-free interest rate) with the portfolio risk expressed by a standard deviation (total risk). Furthermore, the Treynor model is measured by comparing the portfolio risk premium with the risk expressed by beta (market risk). Then Jensen's model emphasizes alpha, which is a measure of the difference between the portfolio's actual rate of return and the market rate of return.

The Treynor model is considered the most appropriate to be used in this study, because it takes into account the market factor (beta) in its calculations. Sharpe's model is less precise, because it takes into account total risk (systematic risk and unsystematic risk). In the formation of optimal portfolios with the Single Index model, unsystematic risks have been minimized by diversification so that they no longer need to be taken into account in the evaluation of portfolio performance. While the Jensen model takes into account the alpha value of the CAPM model, where in this study the model used is the Single Index Model. In addition, Suryani \& Herianti [7] concluded that there was no significant difference between the three previously calculated methods, but the Treynor method had the highest consistency among other methods.

The problem to be resolved through this research is which JII stocks are selected as the optimal portfolio forming stocks? What is the investment weight of each stock in forming the optimal portfolio? What is the value of the expected return and risk generated by the optimal portfolio and its comparison with the market? How is the performance of the portfolio formed by the Treynor approach and how is it compared to the market?

\section{LITERATURE REVIEW}

Portfolio according to Nurmayanti \& Novita [8] is a way for investors to minimize risk by diversifying these risks. Portfolio theory was first formally introduced by Harry
Markowitz in the 1950s and won the Nobel Prize in 1990 for his work. He showed that in general, risk can be reduced by combining several single securities into a portfolio [9].

There are two types of portfolios, namely efficient portfolios, and optimal portfolios. Tandelilin [10] explains that an efficient portfolio is a portfolio with the highest return on a certain risk or a portfolio with the lowest risk with a certain return. Then the optimal portfolio is the portfolio chosen by the investor from the many options available in a collection of efficient portfolios, the selection is adjusted to the preferences of the investor concerned with the returns and risks inherent in the chosen portfolio.

Optimal portfolios are selected from efficient portfolio members, therefore efficient portfolios are not necessarily optimal portfolios, whereas optimal portfolios are definitely efficient portfolios. The optimal portfolio provides the combination of the highest return with the lowest risk [11]. Hartono [10] adds that forming an optimal portfolio can be done by means of Markowitz, with risk-free assets, or with a single index model.

Sharpe's single index model was developed in 1963, with the aim of simplifying the input parameters in the Markowitz Model calculation. Systematically, the relationship between portfolio stock returns and market returns is stated in the following straight line equation [11]:

$$
\mathrm{E}\left(\mathrm{R}_{\mathrm{p}}\right)=\alpha_{\mathrm{p}}+\beta_{\mathrm{p}} \times \mathrm{E}\left(\mathrm{R}_{\mathrm{M}}\right)
$$

\section{Information:}

$\mathrm{E}\left(\mathrm{R}_{\mathrm{p}}\right)$ : Expected portfolio return.

$\alpha_{\mathrm{p}}$ : The component of portfolio stock returns that is independent of market index returns.

$\beta_{\mathrm{p}}$ : Measurement of stock changes due to changes in $R_{M}$.

$\mathrm{R}_{\mathrm{M}}$ : Market index realization returns.

The Single Index Model divides the return of a security into two components, is: (1) A unique (unsystematic) return component represented by ap which is independent of market returns. This uniqueness component relates to micro events that only affect the company concerned, such as the expansion of company operations or plans to reduce labor, and (2) the return component related to market returns represented by $\beta_{\mathrm{p}} \mathrm{R}_{\mathrm{M}}$. The market-related components referred to in this point are related to macro events that affect all companies, such as increases in interest rates and increases in inflation.

In addition to calculating returns, investors also need to consider the level of risk of an investment in making investment decisions. Bodie et al. [12] states that there are two types of risk, namely systematic risk, and unsystematic risk. Systematic risk is the risk inherent in the market, relating to changes that occur in the market in general. Unsystematic risk is the risk associated with the condition of the company which can be eliminated through diversification.

Hartono [11] explains that the optimal portfolio formed based on the Single Index Model has several analysis inputs, namely: (1) Excess Return to Beta (ERB), which is the difference between expected returns and risk-free asset returns, (2) Cut off Points, The optimal portfolio is a portfolio which contains assets that have a high ERB ratio value. Thus, we need a cutoff point that determines the limit 
of how high the ERB value is. The limit point or cut off point, which is then given the symbol $\mathrm{C}^{*}$, is used to determine the stocks that are subsequently included in the optimal portfolio and the shares that are not included in the optimal portfolio, and (3) the proportion of the proportion of funds per share.

Hartono [11] states that there are two measures of portfolio performance, namely through the return itself and the Risk Adjust Return Model. The method for conducting performance appraisals using the return itself is the raw return. Meanwhile, risk adjusted return is the calculation of return that is adjusted to the risk that must be borne. Methods of risk adjusted return include Sharpe ratio, Treynor Ratio, and Jensen Alpha. The Sharpe index was developed by William F. Sharpe in 1965 which emphasized total risk (standard deviation), the Treynor index was developed by Jack L. Treynor in 1966 which emphasized systematic risk as measured by beta, while the Jensen index was developed by E. Michael Jensen in 1968 who emphasized the difference between the actual rate of return obtained by the portfolio and the expected rate of return if the portfolio was on the capital market line.

The Single Index Model is one of the optimum investment portfolio formation methods which is still widely used as a simplification of the Mean Variance formation method, known as the Markowitz Model [13]. Mandal's [14] study concluded that the optimal portfolio investment formation using the Single Sharpe Index Model is easier and more convenient than the Mean-Variance Model (Markowitz Model). This study is based stock samples. This model can show how risky a stock is if the stock is held in a well diversified portfolio.

The Markowitz Model helps to calculate the expected return and portfolio risk, but this model requires a covariance calculation that is too complex when it comes to the number of stocks. Furthermore, William Sharpe developed a Single Index Model which is simpler in calculation [15]. The Single Index Model uses stock index data as a representative of market value. The stock index is an indicator that shows the price movements of certain stocks so that the calculation of the Single Index Model only requires calculating the covariance of a stock with the market index [13].

Septyanto \& Kertopati [5] concluded that the best portfolio calculation is to use the Single Index Model. The expected return generated through the Single Index Model is greater $(0.596 \%)$ than that generated by the Markowitz Model $(0.43 \%)$, and the risk is smaller $(0.264 \%)$ than the Markowitz Model (0.467\%). Furthermore, Oktaviani \& Wijayanto [2] concluded that JII provides a higher return than LQ45, besides the risk of JII is also greater than LQ45.

The JII index really regulates the proportion of debt owned by a company in running its business. Where the total debt should not be more than $45 \%$ of the total assets owned. Debt that is too high will increase the interest expense on the company, so that the high burden of the company to pay off its obligations can create a risk of company bankruptcy [16]. The JII index is related to the Islamic economy, where currently Islamic finance is experiencing very rapid growth in the world.

According to Kempf \& Osthoff [17], this development is due to investors' considerations in investing which not only consider matters related to money but also social, moral, and environmental considerations. One indicator of the growth of Islamic finance, especially in Indonesia, is the development of the number of issuers issuing Islamic securities. To be able to issue sharia securities, the issuer must meet the criteria set by the competent authority, in this case Bapepam-LK or the Financial Services Authority.

Fig. 1 below presents the research framework, starting with the determination of stocks that are consistently included in the JII index in the period December 2014 to November 2019. Furthermore, the optimal portfolio forming stocks are found, and the performance of the portfolio is evaluated using the Treynor approach.

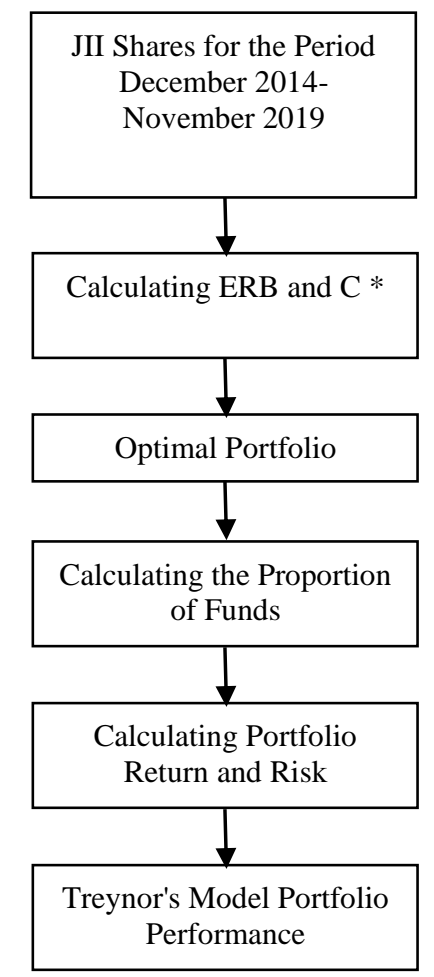

Fig. 1. Research Framework.

\section{RESEARCH METHOD}

This research is quantitative descriptive. The population of this research is issuers that have entered the JII period December 2014 to November 2019. The total population is 48 issuers. The sample of this research is the emissions that are consistent with JII shares during the period December 2014 to November 2019. The sample size is 14 issuers. Data collection was done by using documentation method. The research data is the monthly stock price of each issuer, the JII index, and the BI rate. Data sources are the website yahoo finance, the IDX website, and the Bank Indonesia website. The operational definition and measurement of research variables are as follows:

1) Individual Realized Return

$R_{i}=\frac{P_{t}-P_{t-1}}{P_{t-1}}$

2) Market Realized Return 
$\mathrm{R}_{\mathrm{M}}=\frac{\mathrm{M}_{\mathrm{t}}-\mathrm{M}_{\mathrm{t}-1}}{\mathrm{M}_{\mathrm{t}-1}}$

3) Individual Expected Return

$\mathrm{E}\left(\mathrm{R}_{\mathrm{i}}\right)=\frac{\sum_{i=1}^{n} R_{i}}{n}$

4) Market Expected Return

$\mathrm{E}\left(\mathrm{R}_{\mathbf{M}}\right)=\frac{\sum_{i=1}^{n} R_{\mathbf{M}}}{n}$

5) Variances Individual assets and market assets

$\sigma_{i}^{2}=\frac{1}{n-1} \sum_{t=1}^{n}\left[R_{i}-E\left(R_{i}\right)\right]^{2}$

$\sigma_{\mathbf{M}^{2}}=\frac{1}{n-1} \sum_{t=1}^{n}\left[R_{\mathbf{M}}-E\left(R_{\mathbf{M}}\right)\right]^{2}$

6) Standard Deviation individual and market assets

$\sigma_{i}=\sqrt{\sigma_{i}^{2}}$

$\sigma_{\mathrm{M}}=\sqrt{\sigma_{\mathrm{M}}^{2}}$

7) Beta

$\beta i=\frac{\sigma_{\text {im }}}{\sigma_{\mathrm{m}}{ }^{2}}$

$\sigma_{i m}=\frac{1}{n-1} \sum_{t=1}^{n}\left[\left(\mathrm{R}_{\mathrm{i}}-\mathrm{E}\left(\mathrm{R}_{\mathrm{i}}\right)\right) \times\left(\mathrm{R}_{\mathrm{M}}-\mathrm{E}\left(\mathrm{R}_{\mathrm{M}}\right)\right)\right]$

$\sigma m^{2}=\frac{1}{n-1} \sum_{t=1}^{n}[R m-E(R m)]^{2}$

8) Alpha

$\alpha \mathrm{i}=\mathrm{E}(\mathrm{Ri})-(\beta \mathrm{i} \cdot \mathrm{E}(\mathrm{RM}))$

9) Excess Return to Beta (ERB)

$\mathrm{ERB}=\frac{\mathrm{E}(\mathrm{Ri})-\mathrm{RBR}}{\beta_{\mathrm{i}}}$

10) Sort ERB from largest

11) Calculating the value of $C_{i}$

$A_{j}=\frac{\left[E\left(R_{i}\right)-R B R\right] \cdot \beta_{i}}{\sigma_{i}^{2}}$

$\mathrm{B}_{\mathrm{j}}=\frac{\beta_{\mathrm{i}}}{\sigma_{\mathrm{i}}^{2}}$
$\mathrm{C}_{\mathrm{i}}=\frac{\sigma_{M}^{2} \sum_{j=1}^{i} A_{j}}{1+\sigma_{M}^{2} \sum_{j=1}^{i} \beta_{j}}$

12) Determine the Cut Off Point $\left(\mathrm{C}^{*}\right)$, which is the largest $C_{i}$ value from a series of stock $C_{i}$ values.

13) Issuers that have ERB criteria $\geq C^{*}$ are companies that are included in the optimal portfolio, and vice versa.

14) Proportion of Funds

$$
\mathrm{Z}_{\mathrm{i}}=\frac{\beta_{\mathrm{i}}}{\alpha_{\mathrm{ei}^{2}}}\left(\mathrm{ERB}_{\mathrm{i}}-\mathrm{C}^{*}\right)
$$

$$
\mathrm{W}_{\mathrm{i}}=\frac{\mathrm{Z}_{\mathrm{i}}}{\Sigma_{\mathrm{j}=1^{\mathrm{j}}}^{\mathrm{x}}}
$$

15) Alpha and Beta Portfolio

$$
\begin{gathered}
\alpha_{p}=\sum_{i-1}^{n} \mathrm{w}_{\mathrm{i}} \cdot \alpha_{\mathrm{i}} \\
\beta_{\mathrm{p}}=\sum_{\mathrm{i}-1}^{\mathrm{n}} \mathrm{w}_{\mathrm{i}} \cdot \beta_{\mathrm{i}}
\end{gathered}
$$

16) Systematic Risk $\left(\sigma_{\mathrm{p}}^{2}\right)$ and Unsystematic Risk Portfolio $\left(\sigma_{\mathrm{p}}^{2}\right)$

$$
\begin{aligned}
& \sigma_{p}^{2}=\beta_{p}^{2} \cdot \sigma_{M}^{2} \\
& \sigma_{\mathrm{p}}^{2}=\sum_{\mathrm{i}-1}^{\mathrm{n}} \mathrm{w}_{\mathrm{i}}^{2} \cdot \sigma_{\mathrm{p}}^{2}
\end{aligned}
$$

17) Total Portfolio Risk

$$
\sigma_{\mathrm{p}}=\left(\sigma_{\mathrm{p}}^{2}+\sigma_{\mathrm{p}}^{2}\right)^{0,5}
$$

18) Portfolio Expected Return

$$
\mathrm{E}\left(\mathrm{R}_{\mathrm{p}}\right)=\alpha_{\mathrm{p}}+\beta_{\mathrm{p}} \cdot \mathrm{E}\left(\mathrm{R}_{\mathrm{M}}\right)
$$

19) Treynor Model

$$
R V O=\frac{\overline{\mathrm{r}}_{\mathrm{p}}-\overline{\mathrm{r}}_{f}}{\beta_{\mathrm{p}}}
$$

\section{RESUlT AND DisCUSSION}

JII is an index containing the 30 most liquid stocks among the stocks that also meet the criteria of Islamic sharia. Islamic sharia shares are stocks that do not contradict the principles of sharia in the capital market. The principles referred to here have been agreed upon by the Financial Services Authority together with the Indonesian Ulema Council, from which the Financial Services Authority regulation number: KEP-208/BL/2012 was born regarding 
the criteria and issuance of a list of sharia securities that are included in the Islamic stock index. namely: (1) The business being carried out does not violate the principles of sharia, for example, gambling, counterfeit trading, producing or operating illicit goods, transactions containing elements of bribery, and usury, (2) The ratio of total debt (interest) to total assets not more than $45 \%$, and (3) the total interest income plus non-halal income is not more than $10 \%$ of the total profit.

\section{A. Expected Return}

The value of expected return is used as a reference by investors in investing because it is an expected return that is received later. Fig. 2 shows the issuer that produced a positive expected return (above the line), and a negative expected return (below the line).

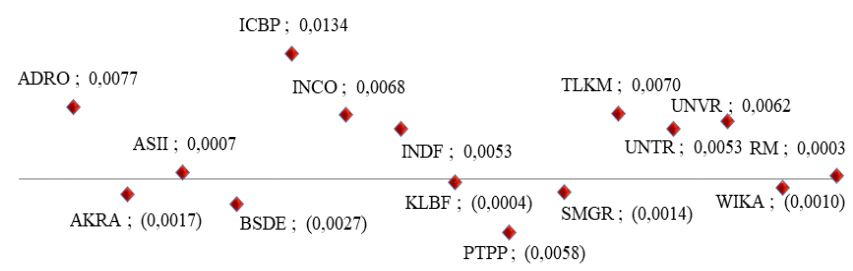

Fig. 2. Expected Return of Each Stock and Market.

Stocks that produce a positive expected return value show that these shares provide benefits for investors. The stock that gave the highest $\mathrm{E}\left(\mathrm{R}_{\mathrm{i}}\right)$ was ICBP which was 0.0134. While the stock that had the lowest $\mathrm{E}\left(\mathrm{R}_{\mathrm{i}}\right)$ was PTPP which was -0.0058 . The average expected rate of return of the issuers who were the research samples or issuers that were consistent in JII during the period December 2014November 2019 was 0.0026 . This means, during that period the average JII stock provided a capital gain of $0.26 \%$.

The results of calculating the expected return and risk of each stock sample are presented in Fig. 3. It can be seen that ICBP produced the highest expected return of 0.0134 with a risk value of 0.0586 . This supports the efficient portfolio theory that if investors invest in ICBP shares, the highest return will be generated with a certain risk.

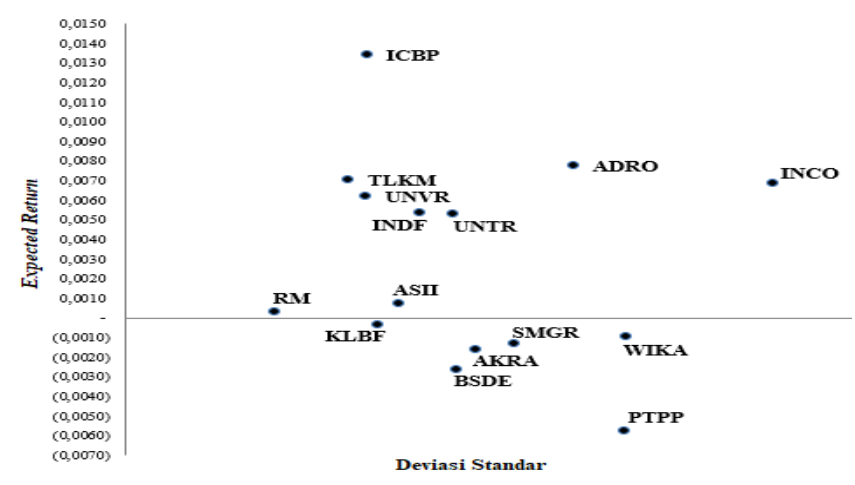

Fig. 3. Expected Return and Deviation Standard.

\section{B. Beta and Alpha}

Fig. 4 shows issuers that produce beta above market beta $(\beta>1)$ and issuers that produce beta below market beta $(\beta$ $<1)$ :

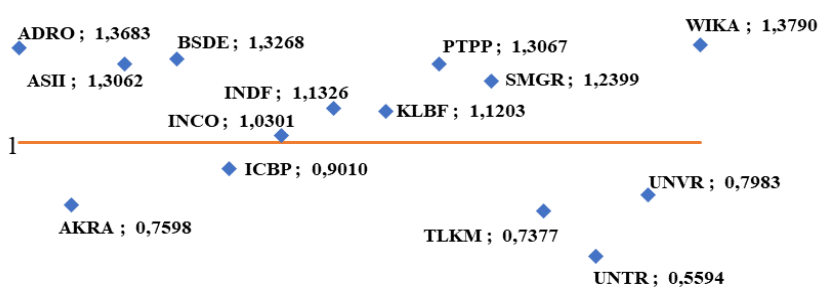

Fig. 4. Beta Value of Each Issuer.

Fig. 4 shows that all stocks have a positive beta value, which means that if there is an increase in the JII market return, it will cause an increase in return on the stock. In other words, stocks with positive beta move in the direction (following) the market. Conversely, if the beta value is negative, it means that the stock value is moving not in the direction of or against the market. The greater the beta value, the greater the sensitivity of the stock to the market.

After calculating the beta value, then calculating the alpha value. Alpha is part of the rate of return that is not influenced by market changes. Alpha is calculated by subtracting the expected return of a stock by multiplying the risk of the stock with the expected market return $\left(\alpha_{i}=E\left(R_{i}\right)\right.$ - $\left(\beta_{\mathrm{i}} . \mathrm{E}\left(\mathrm{R}_{\mathrm{M}}\right)\right)$.

The largest beta is produced by WIKA with a value of 1.3790. This value shows the level of sensitivity of WIKA shares of $37.90 \%(1.3790-1)$ above JII. If the JII index increases by $5 \%$, then WIKA's share price can increase by $6.9 \%(1.379 \times 5 \%)$. Conversely, if the JII index fell by $5 \%$, then WIKA's share price could fall by $6.9 \%$.

The smallest beta is produced by UNTR with a value of 0.5594 . The sensitivity level of UNTR shares is $44.06 \%$ $(0.5594-1)$ below the JII index. If the JII index increases by $5 \%$, UNTR share price could increase by $2.8 \%$. If the JII index goes down, UNTR shares will fall by $2.8 \%$. It can be concluded that the higher the beta value, the greater will be the increase and decrease in the issuer's stock price (negative beta means that the stock movement is opposite to the market).

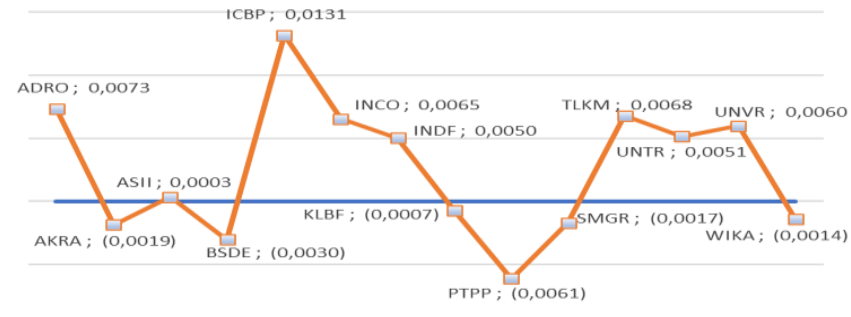

Fig. 5. Alpha Value ( $\alpha)$.

Fig. 5 presents the alpha $(\alpha)$ value of each stock. The highest alpha value is in ICBP shares (0.0131) and the lowest alpha value is in PTPP (-0.0061). The blue line in the figure shows point 0 separating issuers with a positive alpha value (above the blue line) and issuers with a negative alpha value (below the blue line). Alpha with a positive value, means that the issuer provides a single return from its stock performance without being influenced by the market, and vice versa for the issuer that produces a negative alpha. 


\section{Excess Return to Beta (ERB)}

Excess return to beta (ERB) is the excess return on riskfree assets. Risk-free assets are assets whose future returns can be ascertained at this time. Risk-free assets in this study use the BI rate data because it produces representative data compared to other risk-free assets, namely government bonds. The average risk free rate value during the study period (December 2014-November 2019) was 0.0048. Table 3 presents the ERB of each issuer, in order of largest.

\begin{tabular}{llccc}
\multicolumn{5}{c}{ TABLE 2: ERB VALUE } \\
\hline Emiten & E $($ Ri $)$ & Rf & $\boldsymbol{\beta}$ & ERB \\
\hline ICBP & 0,0134 & 0,0048 & 0,9010 & 0,0095 \\
TLKM & 0,0070 & 0,0048 & 0,7377 & 0,0030 \\
ADRO & 0,0077 & 0,0048 & 1,3683 & 0,0021 \\
INCO & 0,0068 & 0,0048 & 1,0301 & 0,0020 \\
UNVR & 0,0062 & 0,0048 & 0,7983 & 0,0017 \\
UNTR & 0,0053 & 0,0048 & 0,5594 & 0,0009 \\
INDF & 0,0053 & 0,0048 & 1,1326 & 0,0005 \\
ASII & 0,0007 & 0,0048 & 1,3062 & $-0,0031$ \\
WIKA & $-0,0010$ & 0,0048 & 1,3790 & $-0,0042$ \\
KLBF & $-0,0004$ & 0,0048 & 1,1203 & $-0,0046$ \\
SMGR & $-0,0014$ & 0,0048 & 1,2399 & $-0,0050$ \\
BSDE & $-0,0027$ & 0,0048 & 1,3268 & $-0,0056$ \\
PTPP & $-0,0058$ & 0,0048 & 1,3067 & $-0,0081$ \\
AKRA & $-0,0017$ & 0,0048 & 0,7598 & $-0,0085$ \\
\hline
\end{tabular}

Table 2 shows that $50 \%$ of JII shares that meet the sample criteria have a positive ERB value, while the other $50 \%$ produce a negative ERB.

\section{Cutoff Point $\left(C^{*}\right)$ and Determination of Optimal Portfolio Shares}

The cutoff point $\left(\mathrm{C}^{*}\right)$ is a comparison between the variance of market returns and the sensitivity of individual stock returns to stock error variance. The $C^{*}$ value of this study is 0.0023 . Issuers that have an ERB value higher or equal to $\mathrm{C}^{*}$ will be included in the optimal portfolio, and conversely, if the ERB value is smaller than $C^{*}$ the issuer will not be included in the optimal portfolio formation. Table 3 presents the calculation of $\mathrm{C}_{\mathrm{i}}$ of each share, determining the cutoff point, and determining the optimal portfolio forming stocks.

TABLE 3: CALCUlation of Ci AND DETERmination of CUTOFF POINT

\begin{tabular}{|c|c|c|c|c|c|c|c|c|c|c|c|c|}
\hline Stocks & Rf & $\beta$ & $\sigma_{i}^{2}$ & $\mathbf{A}_{\mathbf{j}}$ & $\Sigma \mathbf{A}_{\mathbf{j}}$ & $\mathbf{B}_{\mathbf{j}}$ & $\Sigma \mathbf{B}_{j}$ & $\sigma_{M}^{2}$ & $C_{i}$ & $\mathrm{C}^{*}$ & ERB & $\begin{array}{l}\text { Optimal } \\
\text { Stocks }\end{array}$ \\
\hline ICBP & 0,0048 & 0,9010 & 0,0034 & 2,2538 & 2,2538 & 262,30 & 262,30 & 0,0364 & 0,0022 & 0,0023 & 0,0095 & Optimal \\
\hline TLKM & & 0,7377 & 0,0029 & 0,5520 & 2,8058 & 251,31 & 513,61 & & 0,0022 & & 0,0030 & Optimal \\
\hline ADRO & & 1,3683 & 0,0117 & 0,3403 & 3,1461 & 116,72 & 630,33 & & 0,0023 & & 0,0021 & \\
\hline INCO & & 1,0301 & 0,0244 & 0,0853 & 3,2314 & 42,16 & 672,49 & & 0,0023 & & 0,0020 & \\
\hline UNVR & & 0,7983 & 0,0034 & 0,3252 & 3,5567 & 234,10 & 906,59 & & 0,0021 & & 0,0017 & \\
\hline UNTR & & 0,5594 & 0,0063 & 0,0430 & 3,5996 & 88,97 & 995,56 & & 0,0021 & & 0,0009 & \\
\hline INDF & & 1,1326 & 0,0051 & 0,1169 & 3,7165 & 222,46 & 1218,02 & & 0,0019 & & 0,0005 & \\
\hline ASII & & 1,3062 & 0,0044 & $-1,2251$ & 2,4915 & 298,65 & 1516,66 & & 0,0011 & & $-0,0031$ & \\
\hline WIKA & & 1,3790 & 0,0147 & $-0,5461$ & 1,9454 & 94,13 & 1610,79 & & 0,0008 & & $-0,0042$ & \\
\hline KLBF & & 1,1203 & 0,0038 & $-1,5471$ & 0,3983 & 297,51 & 1908,30 & & 0,0001 & & $-0,0046$ & \\
\hline SMGR & & 1,2399 & 0,0088 & $-0,8697$ & $-0,4714$ & 140,90 & 2049,20 & & $-0,0002$ & & $-0,0050$ & \\
\hline BSDE & & 1,3268 & 0,0064 & $-1,5386$ & $-2,0101$ & 205,87 & 2255,07 & & $-0,0007$ & & $-0,0056$ & \\
\hline PTPP & & 1,3067 & 0,0145 & $-0,9526$ & $-2,9626$ & 90,08 & 2345,14 & & $-0,0010$ & & $-0,0081$ & \\
\hline AKRA & & 0,7598 & 0,0072 & $-0,6787$ & $-3,6413$ & 105,32 & 2450,47 & & $-0,0011$ & & $-0,0085$ & \\
\hline
\end{tabular}

Excess return to beta (ERB) is the difference between the stocks expected return and the risk-free interest rate return, which is then divided by systematic risk or beta. Meanwhile, the cutoff point is a comparison between the market return variance and the sensitivity of individual stock returns to the stock error variance.
Based on Table 3, it can be concluded that there are 2 stocks that meet the requirements to be included in the optimal portfolio namely ICBP and TLKM. ICBP is a share in the goods and consumption industry sector - the food and beverage sub-sector and TLKM is included in the Infrastructure, Utility, and Transportation sector - the telecommunications sub-sector.

This finding supports the principle of diversification namely that portfolio formation should use stocks from different industries to reduce the level of risk. Furthermore, Fig. 6 presents a pie chart of the optimal proportion of portfolio funds. It is recommended that $91.46 \%$ of investment funds be placed in ICBP, the remaining $8.54 \%$ are placed in TLKM shares.

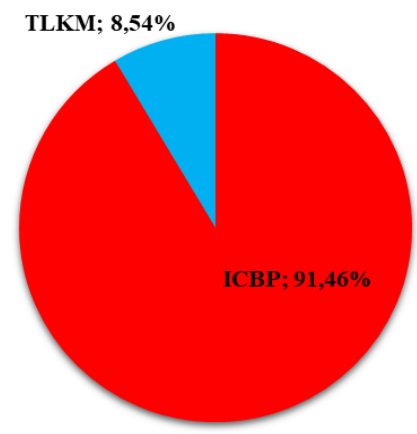

Fig. 6. Optimal Proportion of Portfolio Shares.

\section{E. Portfolio Expected Return}

The optimal portfolio expected return or $E\left(R_{p}\right)$ is the level of profit that investors expect from the optimal portfolio formed. The calculation of the value of the optimal portfolio expected return is based on the alpha value and beta value of the optimal portfolio. Alpha portfolio calculation $\left(\alpha_{p}\right)$ through equation (17) yields an $\alpha_{p}$ value of 0.0126 (1.26\%). Alpha portfolio is the total number of alpha securities stocks that make up the optimal portfolio. The $\alpha_{p}$ value means that the market independent (not influenced) portfolio return is $1.26 \%$. This means that if the market has no effect on the portfolio, the expected return will be 0.0126 .

The portfolio beta $\left(\beta_{\mathrm{p}}\right)$ (calculated through equation 18$)$ is $0.8870(88.7 \%)$. A positive beta portfolio indicates that the portfolio that is formed is moving positively or in the direction of the market. This value indicates the optimal level of portfolio sensitivity is $0.1130(1-0.8870)$ below the JII. If JII's shares increase by $5 \%$, the resulting portfolio can increase by $0.57 \%(0.1130 \times 5 \%)$. The greater the beta value of the portfolio, the greater the sensitivity of the portfolio to the market.

The portfolio's expected return (calculated through equation 22) results in value of $E\left(R_{p}\right)$ of 0.0128 . The value of the optimal portfolio expected return produces a value that is greater than that of the average stock in the market index $\mathrm{E}\left(\mathrm{R}_{\mathrm{M}}\right)$ (which is 0.0003 ) and is also greater than the value of the risk free rate (0.0048).

The value of $E\left(R_{p}\right)$ is greater than the value of $E\left(R_{M}\right)$ and the value of the risk free rate is in line with the research of Suroto [18] and Oktaviani \& Wijayanto [2]. The findings of this study are different from Septyanto \& Bob [5] and 
Firdaus, Anah, \& Nadira [19] which produce an value of $E\left(R_{p}\right)$ which is smaller than the value of $E\left(R_{M}\right)$. Both studies use benchmarks or market indexes that are incompatible with the index used as the object of research. The two researchers examined the LQ45 index, but the market index used was the composite stock price index.

\section{F. Optimal Portfolio Risk}

The risk resulting from the optimal portfolio is 0.0438 , which is greater than the market risk $\left(\sigma_{\mathrm{M}}\right)$ which is 0.0372 . However, the resulting portfolio risk is smaller than the risk generated by the respective issuers. This finding supports the diversification principle that diversification serves to spread risk or minimize investment risk. This risk measurement is also useful for knowing how far the deviation will occur (it is possible that the value to be obtained deviates from the expected).

\section{G. Optimal Portfolio Performance with the Treynor Model}

Optimal portfolio performance measurement is required in the investment process stage. Tandelilin [10] explains that the investment process has five stages namely determining investment objectives, determining investment policies, selecting portfolio strategies, selecting assets, and finally measuring and evaluating portfolio performance. The optimal portfolio performance that has been formed in this study is measured by the Treynor model. The results of the portfolio performance measurement are presented in Table 4 below.

\begin{tabular}{|c|c|c|}
\hline & $\begin{array}{l}\text { Optimal } \\
\text { Portfolio }\end{array}$ & Market \\
\hline Ekspected Return & 0,0128 & 0,0003 \\
\hline Risk Free Rate & 0,0048 & 0,0048 \\
\hline Beta & 0,8870 & 1,0000 \\
\hline RVOL & 0,0091 & $-0,0045$ \\
\hline
\end{tabular}

The optimal portfolio generates a higher Treynor value compared to JII as a benchmark (market). The Treynor index value generated by the optimal portfolio is 0.0091 , while the market is -0.0045 . A positive Treynor value means that the portfolio will provide a return greater than the expected return (Expected Return). On the other hand, the market (JII) produces a return lower than the expected return.

\section{CONCLUSION}

Referring to the discussion that has been described in the previous section, it can be said: (1) By using the Single Index Model, issuers that are included in the optimal portfolio are ICBP and TLKM, (2) Recommended investment weight for each issuer is ICBP $91.46 \%$ and TLKM $8.54 \%$, (3) The resulting expected return portfolio or $\mathrm{E}\left(\mathrm{R}_{\mathrm{p}}\right)$ is 0.0128 greater than the market at 0.0003 and the resulting portfolio risk $\left(\sigma_{\mathrm{p}}\right)$ is 0.0438 greater than the market amounting to 0.0364 , and (4) Portfolio performance calculated using the Treynor model produces good performance because it produces a positive value and is greater than that generated by the market.
Regarding the findings of this study, several suggestions that can be given are: (1) The formation of an optimal portfolio is very important because there is a diversification concept that can minimize the value of risk by spreading risk to stocks that form the optimal portfolio. Investors with a risk averse preference (disliking risk) can form an optimal portfolio as in this study because it produces a small risk compared to the risk generated from individual stocks, (2) The researcher can then form an optimal portfolio on other indices, or continue to do research on the JII index however compares bullish and bearish market conditions.

\section{REFERENCES}

[1] Financial Fervices Authority. (2020). Statistik Pasar Modal. Retrived July, $2^{\text {nd }} 2020$, from http://www.ojk.go.id.

[2] Oktaviani, B. N., \& Wijayanto, A. (2016). Aplikasi Single Index Model dalam Pembentukan Portofolio Optimal Saham LQ45 dan Jakarta Islamic Index. Management Analysis Journal 4 (1) (2015), 189-202.

[3] Medcom.id (2015). Investasi Syariah Lebih Tahan Krisis Ketimbang Konvensional. Retrived September, $1^{\text {st }}$ 2020, from https://www.medcom.id/ekonomi/bursa/yNL00zvN-investasi-syariahlebih-tahan-krisis-ketimbang-konvensional.

[4] Sihombing, P. (2018). Corporate Financial Management. Bogor: IPB Press.

[5] Septyanto, D., \& Kertopati, B. (2014). Analisa Pembentukan Portofolio dengan Menggunakan Model Markowitz dan Single Index Model pada Saham yang Masuk dalam Indeks LQ45 di Bursa Efek Indonesia Tahun 2009-2013. Finance and Banking Journal Vol. 16 (2), 140-156.

[6] Samsul, M. (2015). Pasar Modal dan Manajemen Portofolio. Erlangga.

[7] Suryani, A., \& Herianti, E. (2015). The Analysis of Risk Adjusted Return Portofolio Performance Share For LQ 45 Index in Indonesia Stock Exchange in 2010-2014 Periodes. Procedia Social and Behavioral Sciences Vol. 211, 634-643.

[8] Nurmayanti, P., \& Novita, I. (2010). Dasar-Dasar Analisis Investasi dan Portofolio. Palembang: Citrabooks Indonesia.

[9] Hartono, J. (2010). Teori Portofolio dan Analisis Investasi. Yogyakarta: BPFE.

[10] Tandelilin, E. (2010). Portofolio dan Investasi: Teori dan Aplikasi Edisi Pertama. Yogyakarta: Kanisius.

[11] Hartono, J. (2014). Teori dan Praktik Portofolio dengan Excel. Jakarta: Salemba Empat.

[12] Bodie, Z., Kane, A., Marcus, A. J., \& Jain, R. (2014). Investments. New York: Asian Global Edition.

[13] Elton, E. J., Gruber, M. J., Brown, S. J., \& Goetzmann, W. N. (2013). Modern Portfolio Theory and Investment Analysis, $9^{\text {th }}$ Edition. New York: John Wiley and Sons.

[14] Mandal, N. (2013). Sharpe's Single Index Model and its Applicarion to Construct Optimal Portfolio: an Empirical Study. Great Lakes Herald Vol. 7 (1), 1-34.

[15] Mary, J. F., \& Rathika, G. (2015). The Single Index Model and The Construction of Optimal Portfolio with Cnxpharma Scrip. International Journal of Management Vol. 6 (1), 87-96.

[16] Brigham, E. F. \& Houston, J. F. (2010). Dasar-dasar Manajemen Keuangan. Buku 11: Essentials of Financial Management. Jakarta: Salemba Empat.

[17] Kempf, A., \& Osthoff, P. (2007). The Effet of Socially Responsible Investing on Portfolio Performance. Eurpean Financial Management Vol. 13 No. 5, 908-922.

[18] Suroto. (2015). Analisis Portofolio Optimal Menurut Model Indeks Tunggal Studi Empiris pada Saham LQ 45 di Bursa Efek Indonesia Periode Agustus 2012-Juli 2015). Media Ekonomi dan Manajemen Vol. 30 (2) Juli 2015, 161-177.

[19] Firdaus, I., Anah, S., \& Nadira, F. (2018). Analisis Pembentukan Portofolio Optimal Menggunakan Model Indeks Tunggal (Studi Kasus: Saham LQ45 yang Terdaftar di BEI Tahun 2012-2016). Jurnal Ekonomi Volume XXIII (2) Juli 2018, 203-225. 